\title{
Regulation of breast cancer metastasis by Runx2 and estrogen signaling: the role of SNAI2
}

Nyam-Osor Chimge ${ }^{1,2^{*}}$, Sanjeev K Baniwal ${ }^{2,3}$, Gillian H Little ${ }^{1,2}$, Yi-bu Chen ${ }^{4}$, Michael Kahn ${ }^{1}$, Debu Tripathy ${ }^{5}$, Zea Borok ${ }^{1,5,6}$ and Baruch Frenkel ${ }^{1,2,3^{*}}$

\begin{abstract}
Introduction: In contrast to its role in breast cancer (BCa) initiation, estrogen signaling has a protective effect in later stages, where estrogen receptor (ER) $\alpha$ loss associates with aggressive metastatic disease. We asked whether the beneficial effect of estrogen signaling in late-stage BCa is attributable to the recently reported estrogenmediated antagonism of the pro-metastatic transcription factor Runx2.
\end{abstract}

Methods: MCF7/Rx $2^{\text {dox }}$ breast cancer cells were engineered with a lentivirus expressing Runx2 in response to doxycycline (dox). Cells treated with dox and/or estradiol (E2) were subjected to genome-wide expression profiling, RT-qPCR analysis of specific genes, and Matrige|TM invasion assays. Knockdown of genes of interest was performed using lentiviruses expressing appropriate shRNAs, either constitutively or in response to dox. Gene expression in BCa tumors was investigated using a cohort of 557 patients compiled from publicly available datasets. Association of gene expression with clinical metastasis was assessed by dichotomizing patients into those expressing genes of interest at either high or low levels, and comparing the respective Kaplan-Meier curves of metastasis-free survival.

Results: Runx2 induced epithelial-mesenchymal transition (EMT) evidenced by acquisition of a fibroblastic morphology, decreased expression of E-cadherin, increased expression of vimentin and invasiveness. Runx2 stimulated SNAI2 expression in a WNT- and transforming growth factor (TGF) $\beta$-dependent manner, and knockdown of SNAI2 abrogated the pro-metastatic activities of Runx2. E2 antagonized the pro-metastatic activities of Runx2, including SNAI2 upregulation. In primary BCa tumors, Runx2 activity, SNAI2 expression, and metastasis were positively correlated, and SNAI2 expression was negatively correlated with ER $\alpha$. However, the negative correlation between SNAI2 and ER $\alpha$ in bone-seeking BCa cells was weaker than the respective negative correlation in tumors seeking lung. Furthermore, the absence of ERo in primary tumors was associated with lung- and brain- but not with bone metastasis, and tumor biopsies from bone metastatic sites displayed the unusual combination of high Runx2/SNAI2 and high ERo expression.

Conclusions: E2 antagonizes Runx2-induced EMT and invasiveness of BCa cells, partly through attenuating expression of SNAI2, a Runx2 target required for mediating its pro-metastatic property. That ERo loss promotes non-osseous metastasis by unleashing Run×2/SNAI2 is supported by the negative correlation observed in corresponding tumors. Unknown mechanisms in bone-seeking BCa allow high Runx2/SNAl2 expression despite high ERa level

\section{Introduction}

Metastasis of primary tumors to distant sites is a complex process that involves a sequence of interdependent events including intravasation, survival within the circulation, extravasation, and colonization. Epithelial-

\footnotetext{
* Correspondence: chimgee@usc.edu; frenkel@usc.edu

'Department of Biochemistry \& Molecular Biology, Keck School of Medicine of the University of Southern California, 2250 Alcazar Street, Los Angeles, CA 90033 USA

Full list of author information is available at the end of the article
}

mesenchymal transition (EMT) has been strongly implicated in metastasis [1,2]. During EMT, epithelial cells dissociate from each other, in part due to loss of E-cadherin expression, upregulate mesenchymal markers, acquire a fibroblast-like morphology, reorganize their cytoskeleton, and become more motile and invasive $[1,2]$. Several transcription factors, including members of the SNAI family have been shown to promote EMT and thus tumor dissemination [3-5]. Bone metastasis is a
C Biomed Central

C 2011 Chimge et al.; licensee BioMed Central Ltd. This is an open access article distributed under the terms of the Creative Commons Attribution License (http://creativecommons.org/licenses/by/2.0), which permits unrestricted use, distribution, and reproduction in any medium, provided the original work is properly cited. 
frequent complication of breast cancer $(\mathrm{BCa})$, with distinct gene signatures defining bone-seeking tumors [6-9].

Prolonged exposure to estradiol (E2) is associated with an increased risk of $\mathrm{BCa}$ [10-14]. The mechanisms through which estrogens contribute to $\mathrm{BCa}$ initiation and progression are complex and implicate estrogen receptor (ER)-mediated genomic and nongenomic signaling as well as the action of genotoxic estrogen metabolites [12]. In contrast to E2-mediated carcinogenesis, the presence of ER $\alpha$ is a favorable prognostic marker associated with less invasive tumors, and those negative for ER $\alpha$ are more aggressive [15]. A randomized clinical trial of postmenopausal women receiving equine estrogen treatment revealed a decrease in $\mathrm{BCa}$ incidence [16] and low-dose estradiol treatment has been proposed as a treatment modality for advanced ER $\alpha$-positive $\mathrm{BCa}$ that does not respond to aromatase inhibition [17]. Indeed, introduction of $\mathrm{ER} \alpha$ into $\mathrm{ER} \alpha$-negative $\mathrm{BCa}$ cells attenuated their pro-cancerous properties in vitro [18-21]. Thus, anti-estrogen therapy for BCa patients, while antagonizing the oncogenic properties of estrogens, may inadvertently result in loss of their anti-metastatic property. Better understanding of mechanisms underlying the beneficial role of estrogen signaling in advanced disease may inform the development of novel therapeutic approaches and improved treatment plans for $\mathrm{BCa}$ patients.

Runx2 is a lineage-specific transcription factor with crucial roles in both bone biology and carcinogenesis [22-24]. During development Runx2 is involved in the process of osteogenesis. Targeted disruption of Runx 2 in mice leads to failure of osteoblast differentiation and bone formation [25,26], and Runx2 haploinsufficiency in humans results in the skeletal disorder cleidocranial dysplasia, with a similar phenotype observed in Runx2 haploinsufficient mice [25]. Although Runx proteins have tumor suppressor properties [24], recent studies assigned a role for Runx 2 in promoting breast and prostate cancer metastasis [27-32]. Thus, Runx2 and E2 signaling play dual roles in $\mathrm{BCa}$, with each functioning to either promote or suppress tumor progression. The mechanisms underlying these contrasting manifestations in cancer are poorly understood.

We previously showed that in the presence of ligand, ER $\alpha$ physically binds Runx2 and inhibits expression of several Runx2 target genes [33]; our recent study revealed that in MCF7 BCa cells E2 independently regulated about half of the Runx2-responsive genes [34]. We therefore hypothesized that gene(s) stimulated by Runx2 and inhibited by E2 may contribute to manifestations of the pro-metastatic or tumor suppressor functions of Runx2 and E2, respectively. Using a combination of tissue culture modeling and bioinformatics analysis of gene expression in $\mathrm{BCa}$ biopsies, we present evidence suggesting that SNAI2/SLUG plays a role in mediating the pro- and anti-metastatic effects of Runx2 and E2, respectively.

\section{Materials and methods}

\section{Cell culture assays and reagents}

MCF7 and T47D BCa cells were obtained from the American Type Culture Collection (Rockville, MD, USA). MCF7/Rx $2^{\text {dox }}$ cells, engineered to express Runx2 in response to doxycycline (dox) [34], were maintained in Dulbecco's modified Eagle's medium (DMEM) containing $10 \%$ fetal bovine serum (FBS) and $50 \mu \mathrm{g} / \mathrm{ml}$ Hygromycin B (GIBCO, Carlsbad, CA). Data presented herein were obtained from cells cultured in phenol redfree DMEM containing 10\% charcoal-stripped FBS (Hyclone, South Logan, UT), $0.5 \mu \mathrm{g} / \mathrm{ml}$ dox (Calbiochem, San Diego, CA) and/or 10 nM E2 (Sigma, St Louis, MO). For invasion assays, cells further engineered to constitutively express luciferase were placed in Matrigel $^{\mathrm{TM}}$-containing inserts (BD Biosciences, Bedford, MA) and invasion was assessed based on luciferase activity in cells that had crossed the membrane [30]. The Wnt inhibitor ICG-001 was synthesized as previously described [35]. Mouse monoclonal anti-SNAI2 and antiRunx2 antibodies were from Millipore (Billerica, MA) and Invitrogen (Grand Island, NY), respectively. AntiTGF- $\beta$ type I receptor (TGFBRI) blocking antibody (sc398) and negative control antibody (sc-2027) were from Santa Cruz Biotechnology Inc. (Santa Cruz, CA).

\section{Real-time quantitative RT-qPCR analysis}

Total RNA was extracted using Aurum ${ }^{\mathrm{TM}}$ Total RNA Mini-Kit (BioRad, Hercules, CA) and cDNA was synthesized with iScript Reverse Transcription Kit (BioRad). RT-qPCR was carried out in triplicate using $\mathrm{iQ}^{\mathrm{TM}}$ SYBR Green Supermix (BioRad) and a CFX96 qPCR machine (BioRad). All transcript levels were normalized to that of GAPDH. Primers used for PCR are listed in Additional file 1 .

\section{Gene silencing}

$\mathrm{T} 47 \mathrm{D} / \mathrm{shRx} 2^{\text {dox }}$ cells, conditionally expressing shRNA to silence Runx2 in response to dox, were previously described [36]. For SNAI2 silencing, specific MissionshRNA lentiviral plasmids (SHCLNG) and a negative control shRNA plasmid (SHC002) were purchased from Sigma and packaged as described [30] using HEK293T cells and the helper plasmids pMD.G1 and pCMV. R8.91. Viral particles were used for transduction of MCF7/Rx $2^{\text {dox }}$ cells followed by selection with $1 \mu \mathrm{g} / \mathrm{ml}$ Puromycin (Invitrogen, Carlsbad, CA). Of five shRNAs tested, two were found to reduce SNAI2 expression by $>75 \%$ and the corresponding cells were propagated as 
described above. shRNA sequences used in this study are listed in Additional file 1.

\section{Data mining}

For primary analysis of gene expression profiles in clinical samples, we compiled microarray data from $557 \mathrm{BCa}$ patients by combining three Gene Expression Omnibus (GEO) datasets, GSE2034, GSE2603 and GSE12276 [37-39]. These datasets were generated using Affymetrix chips HG-U133A (GSE2034 and GSE2603) and HGU133plus2 (GSE12276). The Affymetrix CEL files were downloaded into Partek, normalized using the RMA (Robust Multiarray Averaging) method and filtered for common probes using interplatform comparison. The data were standardized by centering and scaling and patients were dichotomized into low and high expressing groups with regard to the indicated genes of interest. Dichotomizing of the tumors according to the ESR1 Affymetrix probe '205225_at' was consistent with the histological definition of their ER status in 329 of 368 cases $(89.4 \%)$ for which pathological annotation was available, and with the molecular definition of their ER status in 177 of 189 cases (93.7\%) where it was based on different processing of the microarray data [9]. Clinical features, including hormonal status, metastasis-free survival time and sites of metastasis, have been compiled from the supplementary information of the published studies $[9,37]$. For each patient, metastasis-free survival was defined as the time interval between surgery and the diagnosis of metastasis. Only tumors with unambiguous information about sites of metastasis were included in the cohort. For metastatic tissue analyses we used the microarray data from 58 archival human breast carcinoma metastasis specimens deposited into GEO under accession number GSE14020 [9]. Because all the data were from publicly available resources, we did not require ethical approval to carry out this study.

Survival analyses and hierarchical clustering were performed using Partek Genomics Suite 6.6 and the correlation study was performed using Graphpad. Functional annotation of gene groups was performed using both the web-based Database for Annotation, Visualization, and Integrated Discovery (DAVID) system [40] and the Ingenuity Pathways Analysis (IPA $\left.{ }^{\mathrm{TM}}\right)$ package.

\section{Results}

\section{Metastasis-related genes in BCa cells are stimulated by} Runx2 and inhibited by E2

A recent study with prostate cancer cells and a doxinducible lentiviral system identified a Runx2-regulated metastasis-related gene network [30]. We used the same system to conditionally express Runx 2 in the ER-positive/Runx2-negative MCF7 BCa cells, and determined the genes that were responsive to $\operatorname{Runx} 2(N=1,081)$ or
E2 $(N=2,435)$ [34]. Interestingly, almost half of the Runx2 responsive genes were also E2-responsive $(N=$ 530) and these 'common' genes are listed in Additional file 2 along with their level of responsiveness to Runx2 and E2. Functional computational analysis linked these 530 'common' genes to angiogenesis and cell movement (Table 1), suggesting their importance in tumor metastasis. A literature survey for the top ten 'common' genes (Table 2) identified three - SNAI2, S100A9 and CXCL12, which have been implicated in cell motility and BCa metastasis $[4,41,42]$. Moreover, SNAI2 and S100A9 were downregulated by E2. These genes may contribute to the pro- and anti-invasive properties of Runx2 and E2, respectively.

\section{Functional link between Runx2, E2 and SNAI2 in BCa}

Of the top 'common' genes, SNAI2 was of particular interest not only because its expression was the second most stimulated by Runx2 (6.6-fold) but also because it was strongly inhibited by E2 (-3.4-fold) (Table 2). Furthermore, the SNAI family of transcription factors is known to play a role in EMT [3-5]. By Western blot analysis, SNAI2 protein was detected in MCF7/Rx $2^{\text {dox }}$ cells only after the induction of Runx2 (Figure 1A). Additional support for the regulation of SNAI2 by Runx2 was provided by RT-qPCR analysis of other cell types, namely $\mathrm{C} 4-2 \mathrm{~B} / \mathrm{Rx} 2^{\text {dox }}$ prostate cancer cells, in which SNAI2 was stimulated by dox-induced Runx2 (Figure $1 \mathrm{~B}$ ), and $\mathrm{T} 47 \mathrm{D} / \mathrm{shRx} 2^{\text {dox }} \mathrm{BCa}$ cells, in which SNAI2 expression was inhibited after dox-induced shRNA-mediated silencing of endogenous Runx2 (Figure $1 C)$. We then sought evidence for the positive and negative regulation of SNAI2 by Runx 2 and ER $\alpha$, respectively, in BCa tumors. We compiled a cohort of 557

\section{Table 1 Functional Annotation Clustering of Genes Independently Regulated by Runx2 and E2 in MCF7/ Rx2 ${ }^{\text {dox }}$ Cells}

\begin{tabular}{lll}
\hline Category & Term & $\boldsymbol{P}$ value \\
\hline $\begin{array}{l}\text { Annotation } \\
\text { Cluster 1 }\end{array}$ & Enrichment Score: 4.50 & \\
GOTERM_BP_FAT & GO:0001944 vasculature development & $2.22 \mathrm{E}-05$ \\
GOTERM_BP_FAT & $\begin{array}{l}\text { GO:0048514 blood vessel } \\
\text { morphogenesis }\end{array}$ & $2.72 \mathrm{E}-05$ \\
GOTERM_BP_FAT & GO:0001568 blood vessel development & $5.40 \mathrm{E}-05$ \\
Annotation & Enrichment Score: 4.48 & \\
Cluster 2 & & $2.55 \mathrm{E}-05$ \\
GOTERM_BP_FAT & GO:0016477 cell migration & $3.77 \mathrm{E}-05$ \\
GOTERM_BP_FAT & GO:0048870 cell motility & $3.77 \mathrm{E}-05$ \\
GOTERM_BP_FAT & GO:0051674 localization of cell &
\end{tabular}

DAVID Functional Clustering brings the similar, redundant, and heterogeneous annotation contents from the same or different resources into annotation groups. Enrichment Score ranks the significance of biological functions and measured as geometric mean of member's $P$-values in a corresponding annotation cluster. Shown are the top two annotation clusters for the 530 'common' genes, those independently regulated by Runx2 and E2. 
Table 2 Genes Independently Regulated by Runx2 and E2 in MCF7/Rx2 ${ }^{\text {dox }}$ Cells

\begin{tabular}{lcccc}
\hline \multirow{2}{*}{ Genes } & \multicolumn{2}{c}{ dox (Runx2)/Control } & \multicolumn{2}{c}{ E2/Control } \\
\cline { 2 - 5 } & fold change & $\boldsymbol{p}$ value & fold change & $\boldsymbol{P}$ value \\
\hline RIS1 & 6.81 & $5.94 \mathrm{E}-08$ & 1.53 & $7.19 \mathrm{E}-04$ \\
SNAI2 & 6.59 & $1.87 \mathrm{E}-07$ & -3.38 & $4.82 \mathrm{E}-06$ \\
SGK & 4.77 & $1.91 \mathrm{E}-09$ & 4.81 & $3.60 \mathrm{E}-09$ \\
C20orf114 & 4.77 & $1.87 \mathrm{E}-07$ & -1.52 & $6.72 \mathrm{E}-04$ \\
C10orf81 & 4.61 & $2.20 \mathrm{E}-07$ & -2.16 & $2.43 \mathrm{E}-05$ \\
MGP & 4.52 & $1.37 \mathrm{E}-07$ & 5.59 & $1.21 \mathrm{E}-07$ \\
CRISPLD2 & 4.49 & $7.78 \mathrm{E}-08$ & -1.96 & $1.72 \mathrm{E}-05$ \\
S100A9 & 3.98 & $4.19 \mathrm{E}-06$ & -1.59 & $3.28 \mathrm{E}-03$ \\
PLAC8 & 3.83 & $9.95 \mathrm{E}-07$ & -1.60 & $7.39 \mathrm{E}-04$ \\
CXCL12 & 3.67 & $1.99 \mathrm{E}-07$ & 3.58 & $4.32 \mathrm{E}-07$ \\
\hline Of 530 Co
\end{tabular}

Of 530 'Common Genes' (Supplemental Table 2), the ten most strongly stimulated by Runx2 are listed along with fold expression change in response to Runx2 and E2, as well as the corresponding $p$ values. Negative values indicate repression.
BCa patients from the publicly available datasets GSE2034, GSE2603 and GSE12276 [37-39] and initially investigated the correlation between SNAI2 expression and a Runx 2 metagene, the latter defined as the average normalized expression of all genes that Runx2 stimulated by $\geq 2$-fold in the MCF7/Rx2 ${ }^{\text {dox }}$ system (except SNAI2 itself). As shown in Figure 1D, there was a positive correlation between expression of SNAI2 and the Runx2 metagene across the $557 \mathrm{BCa}$ patient cohort. On the other hand, SNAI2 expression in the clinical specimens was negatively correlated with ER $\alpha / E S R 1$ : tumors with low ESR1 expression (mostly histologically ERnegative) had significantly more SNAI2 transcripts than those with high ESR1 expression (Figure 1E), and the latter (mostly ER-positive tumors) exhibited a negative correlation between ESR1 and SNAI2 expression (Figure $1 F)$. These data suggest that SNAI2 is stimulated by Runx 2 and inhibited by E2 not only in the MCF7/

\section{A MCF7/Rx2 dox \\ B $\quad \mathrm{C} 4-2 \mathrm{~B} / \mathrm{R} \times 2^{\mathrm{dox}}$ \\ C T47D/shRx2 ${ }^{\mathrm{dox}}$}

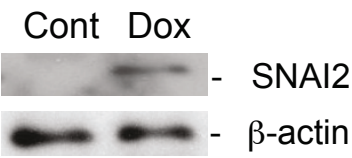

D

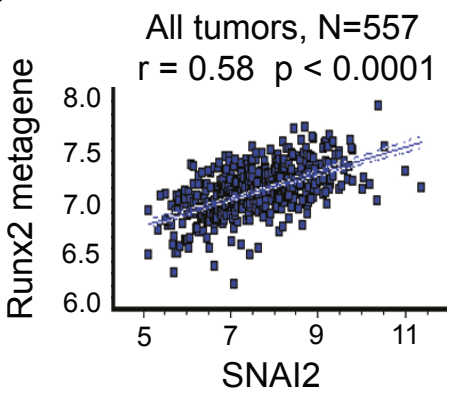

Linear Regression

- - - 95\% Confidence Interval

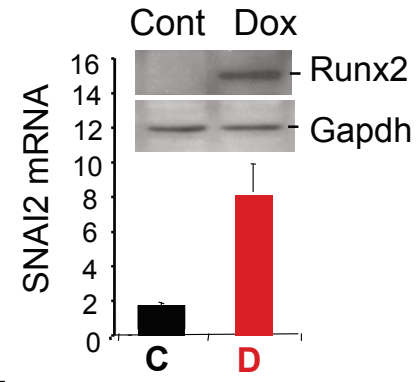

E

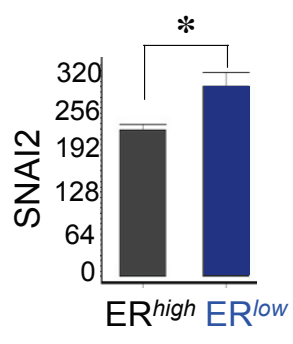

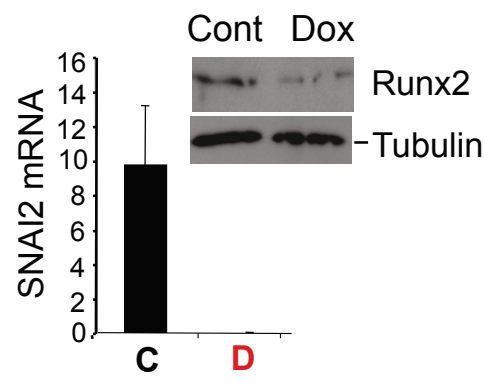

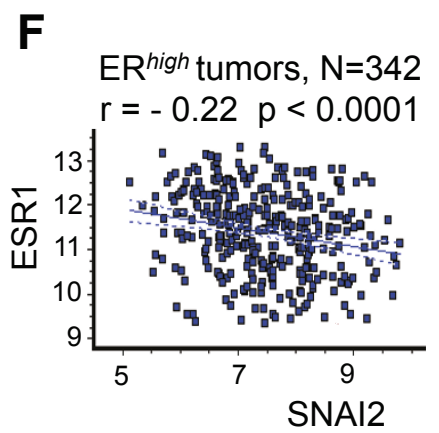

Figure 1 Relationships between Runx2, E2 and SNAI2 in BCa. (A) Runx2 was induced by treating MCF7/Rx2 ${ }^{\text {dox }}$ BCa cells with dox for 48 hours, and the effect on SNAI2 protein level was assessed by Western blot analysis of nuclear extracts. (B-C) Runx2 was either induced for 48 hours by dox treatment of $C 4-2 B / R \times 2^{\text {dox }}$ PCa cells (B) or silenced by 48 -hour dox treatment of T47D/shRx ${ }^{\text {dox }}$ BCa cells (C), and the effects on SNAI2 expression were analyzed by RT-qPCR. Western blot analysis of whole cell extracts confirms the respective dox-induced induction and silencing of Runx2. (D) Correlation between SNAI2 mRNA and Runx2 activity in a cohort of 557 BCa tumors. Runx2 activity was defined as the average normalized expression of genes that Runx2 stimulated by $\geq 2$ fold in the MCF7/Rx2 ${ }^{\text {dox }}$ cell culture model, except SNAI2 itself. (E) Expression of SNAI2 mRNA in the same cohort, comparing tumors with high versus low ESR1/ERa levels. Asterisk (*) indicate statistically significant difference $(P<0.05)$ based on unpaired t-test with Welch correction of the log2-transformation of the signal intensities. (F) Analysis of the tumors with high ESR1/ER $\alpha$ expression for correlation between ESR1/ER $\alpha$ and SNAI2. The patient cohort for D-F was compiled from the publicly available GEO datasets GSE2034, GSE2603 and GSE12276 [37-39]. BCa, breast cancer; dox, doxycycline; E2, estradiol; ESR1/ER, estrogen receptor alpha; GEO, Gene Expression Omnibus; PCa, prostate cancer; RT-qPCR; reverse transcription - quantitative polymerase chain reaction; Runx2, runt related transcription factor 2; SNAI2, snail homolog 2. 
$\mathrm{Rx} 2^{\text {dox }}$ model (Table 2 ), but also in other cell lines, as well as in $\mathrm{BCa}$ tumors.

\section{E2 antagonizes Runx2-induced EMT and invasiveness in vitro}

Because SNAI2 has been implicated in EMT and in the invasive metastatic behavior of breast and other cancer cells $[3,4]$ we employed the MCF7/Rx2 ${ }^{\text {dox }}$ culture system to test the hypotheses that Runx2 induces and E2 antagonizes EMT and invasiveness, and that SNAI2 plays a role in these processes. We initially measured by RTqPCR the expression levels of EMT and motility-related genes in MCF7/Rx2 ${ }^{\text {dox }}$ cells treated with dox, E2, or both together. Consistent with the microarray results (Table 2), SNAI2 expression was increased by 9.7 fold and repressed by 4.6 fold in response to 48 -hour treatment with dox and E2, respectively (Figure 2A). The mRNA for another well-established marker of motility and invasion, S100A4 $[43,44]$, was also stimulated by Runx2. Although E2 did not affect basal S100A4 expression, it completely blocked the Runx2-mediated induction (Figure 2A). Despite the stimulation of SNAI2 and S100A4 by Runx2, these changes in gene expression were not accompanied by either noticeable morphological changes (data not shown) or a decrease in the epithelial marker E-cadherin (CDH1) or an increase in the mesenchymal marker vimentin (VIM) (Figure 2A). Taken together these results suggest that induction of Runx2 for two days at best initiated partial EMT in MCF7 cells.

We further assessed expression of EMT and motilityrelated genes seven days after Runx2 induction in
A
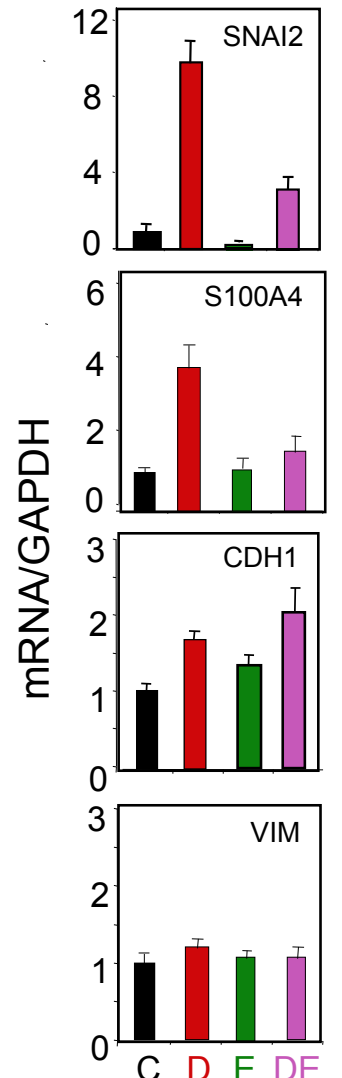

B
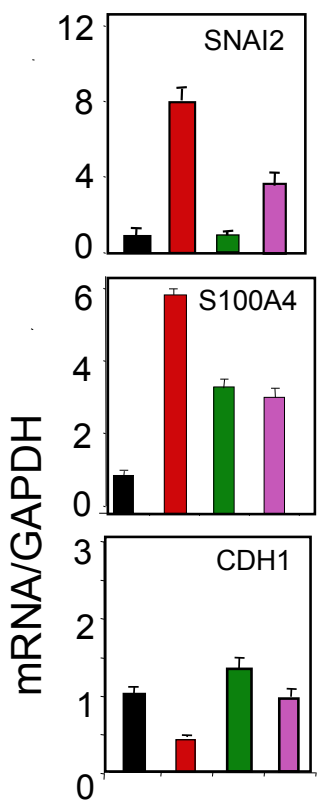

3

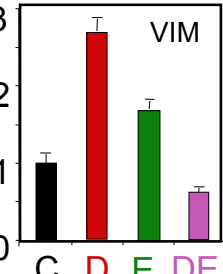

C

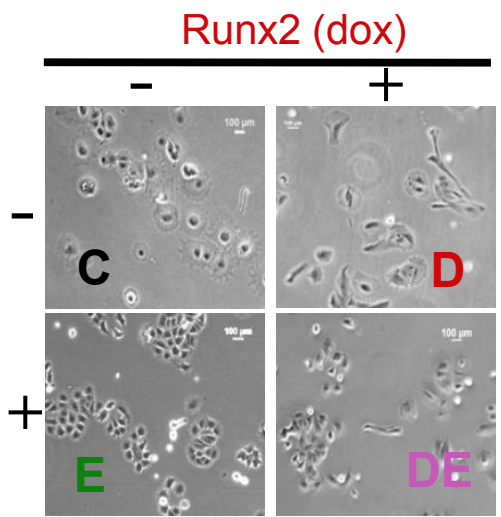

D

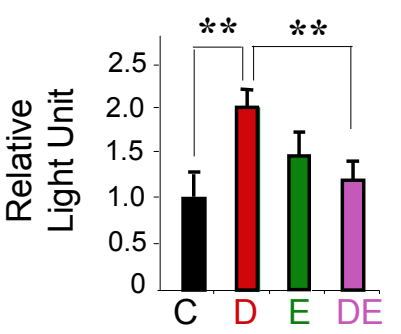

Figure 2 E2 antagonizes Runx2-induced EMT markers and invasiveness of MCF7/Rx2 ${ }^{\text {dox }}$ BCa cells. (A) MCF7/Rx ${ }^{\text {dox }}$ cells were maintained for two days in medium supplemented with CSS and then treated for two days with either vehicle control (C), dox (D), E2 (E), or both stimulants (DE), followed by RT-qPCR analysis of SNAI2, S100A4, vimentin (VIM) and E-cadherin (CDH1) mRNAs. (B) Relative expression of the same marker genes after treatment as in $\mathbf{A}$ for seven days. (C) Phase-contrast images of MCF7/Rx2 ${ }^{\text {dox }}$ cells after seven days of treatments as indicated. (D) MCF7/Rx2 ${ }^{\text {dox }}$ cells transduced with lentiviruses constitutively expressing firefly luciferase were placed in BD Biocoat ${ }^{\mathrm{TM}}$ Transwell inserts with Matrige|$\left.\right|^{\mathrm{TM}}$ and treated for 24 hours as indicated. Luciferase activity in cells that invaded through the Matrige| ${ }^{\mathrm{TM}}$ membrane is presented relative to the average control value (Mean $\pm \mathrm{SD} ; n=3$; ${ }^{*} P<0.01$ ). CSS, charcoal stripped serum; dox, doxycycline; E2, estradiol; EMT, epithelial-mesenchymal transition; RT-qPCR; reverse transcription - quantitative polymerase chain reaction; Runx2, runt related transcription factor 2; S100A4, S100 calcium binding protein A4; SNAI2, snail homolog 2. 
MCF7/Rx $2^{\text {dox }}$ cells. As shown in Figure 2B, this prolonged induction resulted in a more complete EMT. Not only were SNAI2 and S100A4 stimulated, CDH1 was downregulated and VIM was upregulated. Finally, microscopic examination of cultures seven days after Runx2 induction demonstrated a fibroblast-like and scattered morphology as compared to control cultures (Figure 2C). Thus, the partial EMT indicated by increased SNAI2 and S100A4 expression on day 2 (Figure 2A) developed into a more comprehensive EMT phenotype by day 7. More importantly, E2 significantly antagonized most of the Runx2-induced EMT characteristics. It blunted the Runx2-mediated effects on SNAI2 and CDH1 expression, and attenuated the Runx2-mediated effects on the expression of VIM and S100A4 (Figure 2B), as well as its effects on cell morphology (Figure 2C).

Finally, we measured the effects of Runx2 and E2 on BCa cell invasiveness. MCF7/Rx2 ${ }^{\text {dox }}$ cells were transduced with lentiviruses constitutively expressing firefly luciferase and placed on top of Matrigel ${ }^{\mathrm{TM}}$ membranes within BD Biocoat ${ }^{\mathrm{TM}}$ inserts. Luciferase activity associated with cells that had crossed the membrane, a measure of invasiveness [30], was two-fold higher in cultures treated with dox to induce Runx2 as compared to controls, while co-treatment with E2 attenuated the Runx2-mediated invasiveness (Figure 2D). E2 alone had little, if any, effect on MCF7/Rx2 ${ }^{\text {dox }}$ cell invasiveness through Matrigel ${ }^{\mathrm{TM}}$.

\section{SNAI2 plays a critical role in Runx2-mediated MCF7 cell invasion}

We next tested the hypothesis that SNAI2 was required for Runx2-mediated EMT and invasion in MCF7/Rx2 ${ }^{\text {dox }}$ $\mathrm{BCa}$ cells. To this end, MCF7/Rx $2^{\mathrm{dox}} \mathrm{BCa}$ cells were transduced with lentiviruses expressing two independent shRNAs, sh1-SNAI2 and sh2-SNAI2, which target distinct regions of the SNAI2 transcript. Both shRNAs reduced SNAI2 mRNA levels by $>75 \%$ compared to cells expressing a control shRNA (Figure 3A). Cells were then treated with dox and/or E2, followed by RTqPCR analysis of EMT markers and Matrigel ${ }^{\mathrm{TM}}$ invasion assays. Remarkably, SNAI2 knockdown by RNA interference abolished the Runx2-mediated decrease in CDH1 mRNA and increase in VIM mRNA, implicating SNAI2 in Runx2-mediated EMT (Figure 3B). Although SNAI2 silencing did not antagonize the stimulation of S100A4 by Runx2 (Figure 3B), it completely abrogated the ability of Runx2 to increase MCF7 cell invasion through Matrigel $^{\mathrm{TM}}$ (Figure 3C).

WNT and TGF $\beta$ signaling are required for Runx2-mediated stimulation of SNAI2 expression

EMT is regulated by various signal transduction pathways including WNT and TGF $[45,46]$, and IPA ${ }^{\mathrm{TM}}$ analysis of the 530 'common' genes for representation of developmental and growth factor signaling pathways indicated enrichment of $\mathrm{WNT} / \beta$-catenin pathwayrelated genes (Figure 4A). Both the WNT and TGF $\beta$ pathways have been also implicated in the regulation of SNAI2 expression $[47,48]$. Given that SNAI2 was required for Runx2-mediated EMT and invasiveness, we asked whether Runx2-mediated stimulation of SNAI2 expression involved WNT and TGF $\beta$ signaling pathways. To this end, MCF7/Rx $2^{\text {dox }}$ cells were treated with dox, E2 or both, along with inhibitors of either WNT or TGF $\beta$ signaling. WNT signaling was inhibited by using ICG-001, a small molecule that interferes with the recruitment of CAAT-enhancer binding protein (CBP) to $\beta$-catenin/LEF/TCF complexes [35]. For TGF $\beta$ blockade, we used neutralizing antibodies against TGFBR1. As shown in Figure 4B, both ICG-001 and the antiTGFBR1 antibody attenuated Runx2-induced SNAI2 expression. Interestingly, attenuation of the Runx2 response with either ICG-001 or the anti-TGFBR1 antibodies was no longer observed in cells co-treated with both dox and E2 (Figure 4B). Co-blockade of the WNT and TGF $\beta$ pathways was as effective as blocking each separately (data not shown). Thus, inhibition of either WNT or TGF $\beta$ signaling, or the presence of E2, suppressed Runx2-stimulated SNAI2 expression in MCF7 BCa cells. Neither WNT nor TGF $\beta$ interference affected Runx2-stimulated SNAI2 expression in the presence of E2. These results suggest that the WNT and TGF $\beta$ blockade may have targeted the same pathways by which E2 antagonizes Runx2 in BCa cells.

\section{Negative association of SNAI2 with metastasis-free survival in $\mathrm{BCa}$ patients}

We next determined the association between SNAI2 expression level and clinical BCa progression by constructing Kaplan-Meier curves for overall or site-specific metastasis-free survival of tumors expressing either high or low levels of SNAI2. Of the 557 patients compiled from the publicly available datasets GSE2034, GSE2603 and GSE12276 [37-39], 288 (52\%) relapsed, with 184, 28 and 76 developing bone, brain and lung metastasis, respectively $[38,39]$. In cases of metastasis to multiple organs, each of the corresponding sites was included in the analysis. Overall, tumors expressing SNAI2 at high levels were more likely to relapse than those with low SNAI2 expression (Figure 5A-D). Accordingly, tumors which did not metastasize were mostly SNAI2 ${ }^{\text {low }}$ (Figure $5 \mathrm{M}$ ). The association between SNAI2 expression and metastasis was particularly strong for bone $(P=4.04 \mathrm{E}-010)$ (Figure $5 \mathrm{D})$. These results suggest that high expression of SNAI2 in $\mathrm{BCa}$ primes tumors for metastasis in general and bone metastasis in particular. 

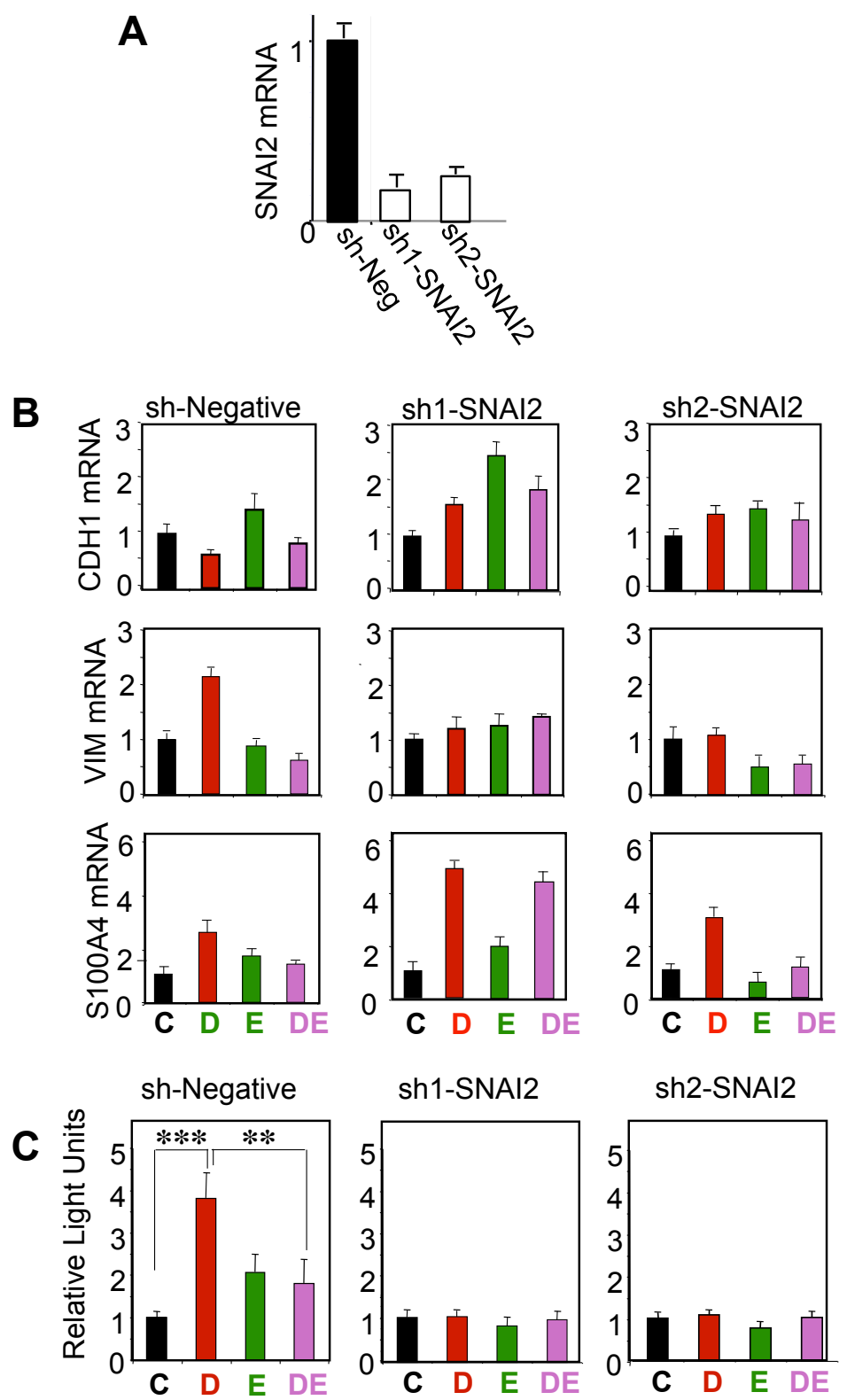

Figure 3 SNAI2 is required for Runx2-mediated EMT. (A) RT-qPCR analysis of SNAI2 mRNA in MCF7/Rx2 ${ }^{\text {dox }}$ cells transduced with a control (sh-Neg) or each of two independent SNAI2 shRNA lentiviruses. (B-C), MCF7/Rx2 ${ }^{\text {dox }}$ cells transduced with sh1-SNAI2, sh2-SNAI2, or the negative control virus were treated with vehicle control (C), dox (D), E2 (E), or both stimulants (DE). The effects of SNAI2 knockdown on expression of the indicated EMT markers were assessed by RT-qPCR after seven days and the effects on invasion were assessed using Matrige $\left.\right|^{\mathrm{TM}}$-COntaining BD Biocoat ${ }^{\mathrm{TM}}$ Transwells as in Figure 2D, except dox treatment was initiated 6 hours prior to placing the cells in the transwell chambers. ${ }^{* *}, P<$ 0.01 ; **, $P<0.005$. Dox, doxycycline; EMT, epithelial-mesenchymal transition; E2, estradiol; RT-qPCR, reverse transcription - quantitative polymerase chain reaction; Runx2, runt related transcription factor 2; SNAI2, snail homolog.

Anomalous high expression of SNAI2, Runx2 and ER $\alpha$ in bone-seeking $\mathrm{BCa}$ tumors

Suppression of SNAI2 expression in BCa cells by E2 (Figure 2A) may be related to the protective effect of ER $\alpha$ against metastasis. Indeed, consistent with previous reports [15,17-21], tumors with high ESR1 expression were less likely to metastasize in our cohort, particularly during the initial 20 to 40 months after surgery (Figure $5 \mathrm{E})$. Analysis of the association between ESR1 expression and metastasis to specific sites, however, revealed an interesting exception. Whereas high ESR1 expression was negatively correlated with lung and brain metastasis (Figure 5F-G), it positively correlated with bone metastasis (Figure 5H). Thus, unleashing SNAI2 gene 


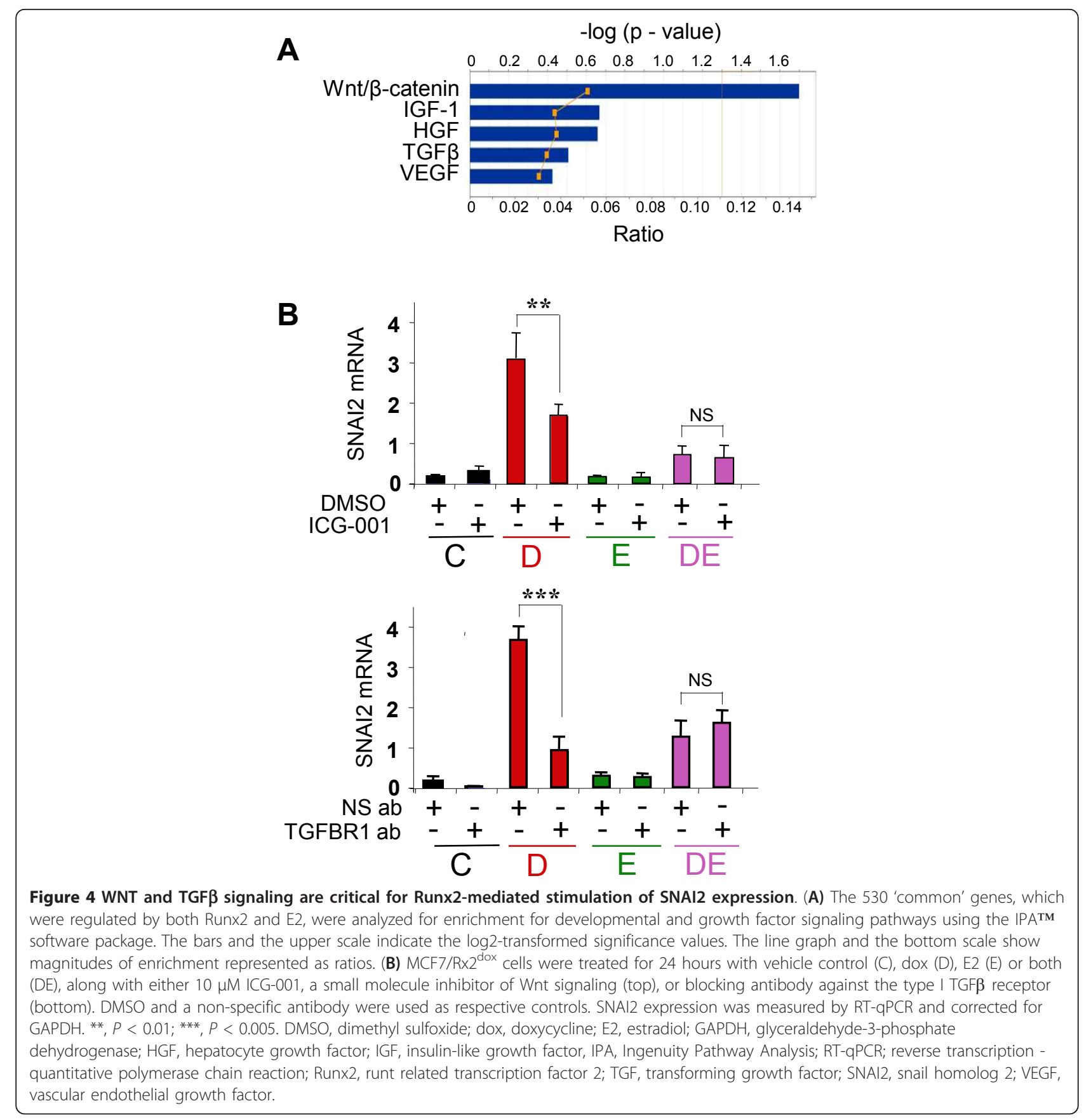

expression by loss of $\mathrm{ER} \alpha$ is a plausible mechanism promoting metastasis in general; however, high expression of SNAI2 in cells that metastasize to bone occurs despite high ESR1 expression. Furthermore, SNAI2 expression was associated with lung and brain metastasis only for tumors expressing low levels of ESR1 (Figure $5 \mathrm{~J}-\mathrm{K})$, whereas bone metastasis was associated with SNAI2 for tumors expressing ESR1 at either low or high levels (Figure 5L), suggesting weaker control of SNAI2 by $\mathrm{ER} \alpha$ in bone-seeking tumors. Consequently, the combination of low ESR1 and high SNAI2 expression was predominant within lung and brain-seeking tumors (Figure 5O-P), whereas bone-seeking tumors were mostly those expressing both ESR1 and SNAI2 at high levels (Figure 5Q). Consistent with these observations, the negative correlation between ESR1 and SNAI2 expression was weaker in bone compared to lung-seeking tumors (Figure 5R-U; brain-seeking tumors were not analyzed because only eight of them were ER-positive). Finally, we investigated Runx2, SNAI2 and ESR1 gene 

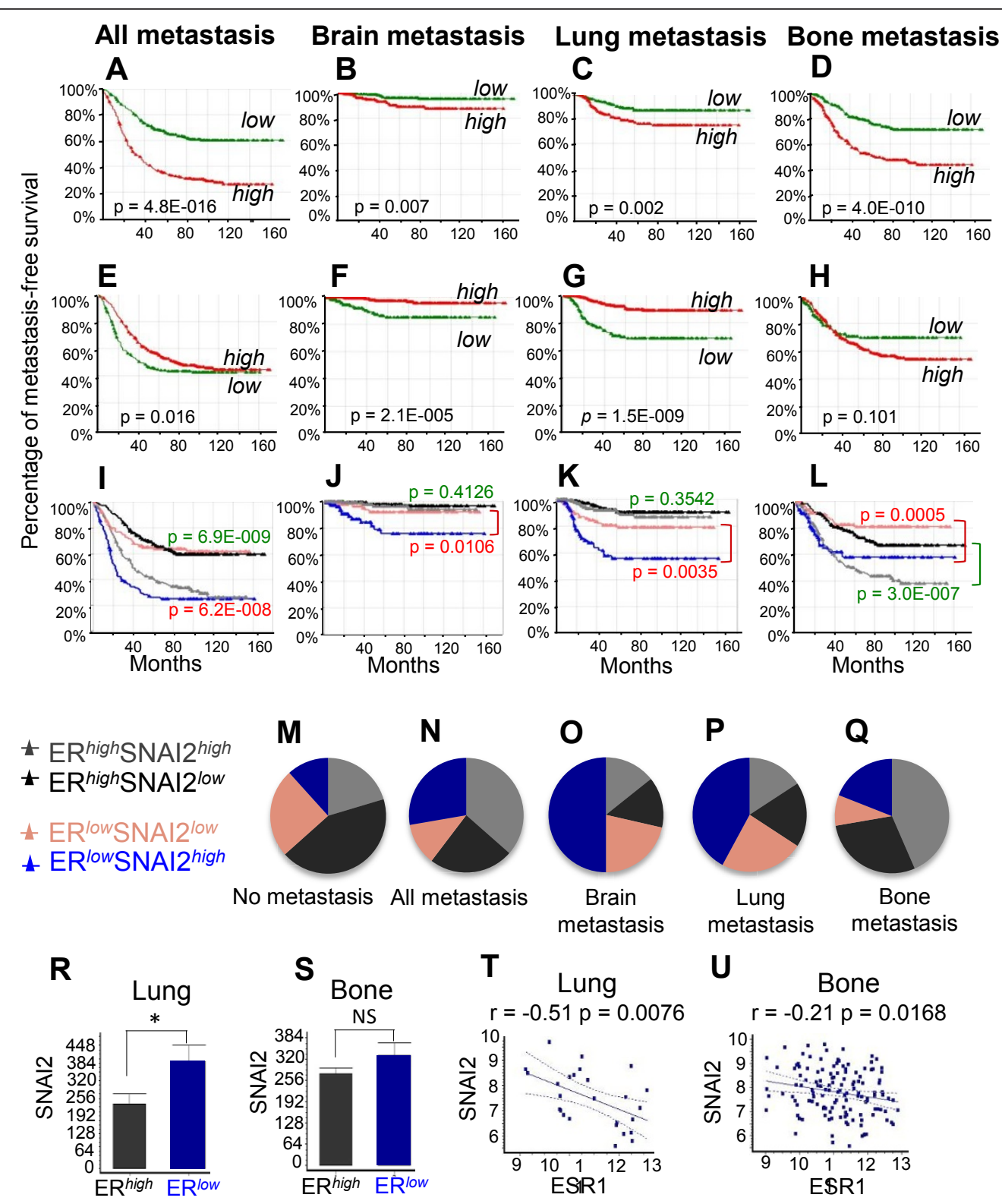

Lung
metastasis

metastasis

U Bone
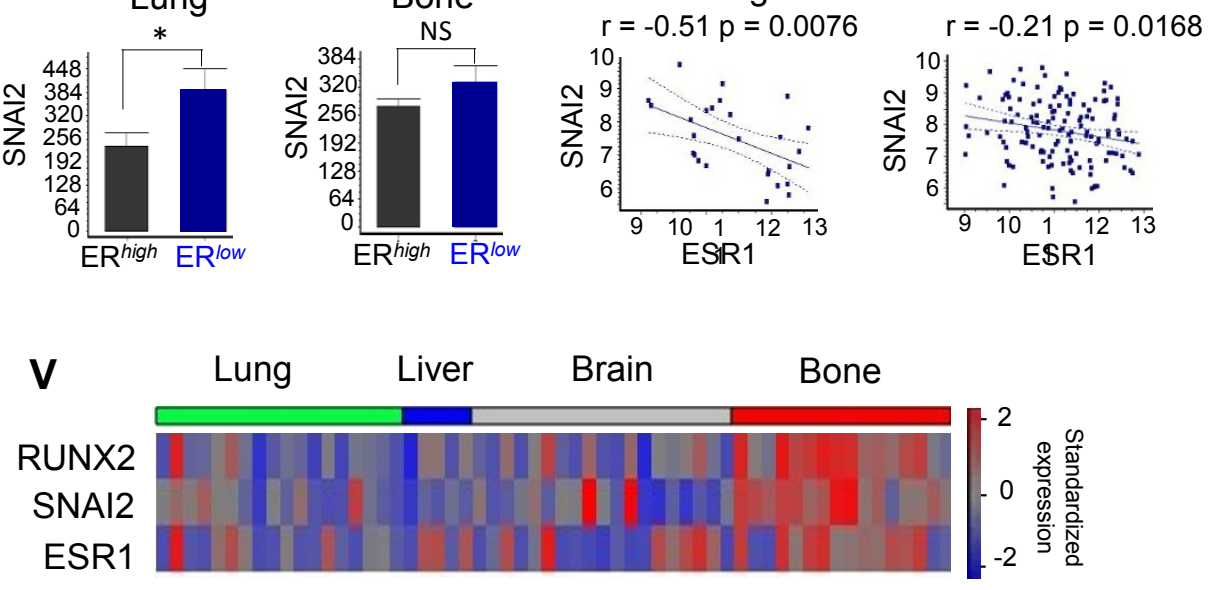

Figure 5 Association of SNAI2 and ER $\alpha$ expression with metastasis. A cohort of 557 BCa tumors compiled from the GEO datasets GSE2034, GSE2603 and GSE12276 [37-39], was dichotomized into groups expressing either high or low levels of either SNAI2 or ESR1/ERo, and KaplanMeier curves were constructed for the probability of overall or organ-specific metastasis-free survival in each group. (A-D) Kaplan-Meier curves of overall, brain, lung and bone metastasis-free survival in the cohort of 557 patients according to SNAI2 expression status. (E-H) Kaplan-Meier curves of overall, brain, lung and bone metastasis-free survival in the cohort according to ER $\alpha$ expression status.(I-L) Kaplan-Meier curves of overall, brain, lung and bone metastasis-free survival were generated for the 342 ER $\alpha$-positive (black and grey curves) and 215 ER $\alpha$-negative (blue and pink curves) tumors based on high versus low expression of SNAI2. Significance of association was determined by logrank test and the P-values are depicted for ER $\alpha$-positive (green), and ER $\boldsymbol{\alpha}$-negative tumors (red). (M-Q) Expression status of SNAl2 and ER $\boldsymbol{\alpha}$ in tumors that either 


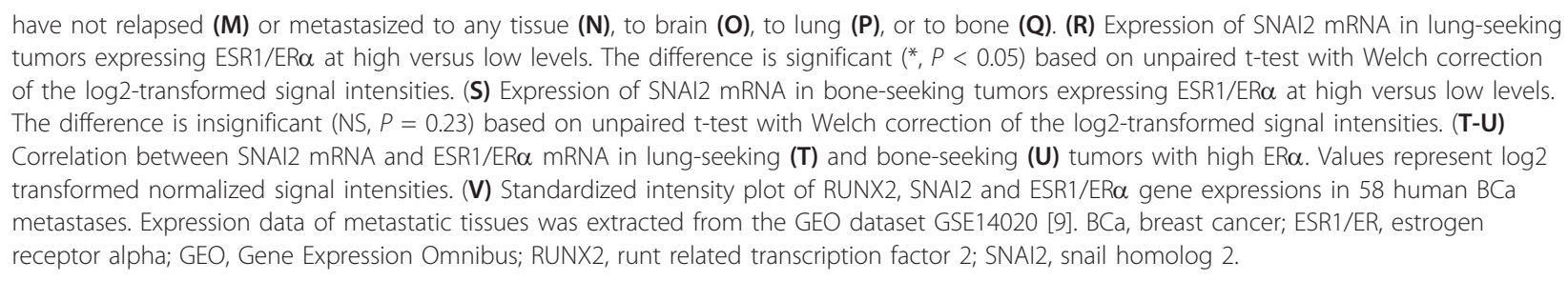

expression in $58 \mathrm{BCa}$ tumors derived from metastatic sites: 16 from bone, 19 from brain, 18 from lung and 5 from liver [9]. The standardized signal intensities plot showed preferential upregulation of Runx2, SNAI2 and ESR1 in the bone-derived biopsies (Figure 5V). The unusual concomitant high expression of ESR1 and Runx2/SNAI2 may reflect dominant regulation of Runx2/SNAI2 by E2-resistant signaling pathways that promote $\mathrm{BCa}$ bone metastasis.

\section{Discussion}

Apart from promoting $\mathrm{BCa}$ progression, estrogen signaling has paradoxical anti-metastatic properties $[15,17,19-21]$. Potentially contributing to this, E2 antagonized the transcription factor Runx2, whose role in metastasis is being increasingly recognized [22,24,30-32]. Specifically, Runx2 promoted EMT and invasion of $\mathrm{BCa}$ cells in vitro, and this was antagonized by E2 (Figure 2). At the center stage of the opposing effects of Runx2 and E2 signaling on EMT and invasion was the transcription factor SNAI2. Consistent with previous reports $[30,48,49]$, SNAI2 was stimulated by Runx 2 and inhibited by E2 (Figure 1A and 2A); Runx2 no longer enhanced EMT and invasion after SNAI2 knockdown; SNAI2 expression in $\mathrm{BCa}$ biopsies positively correlated with a metagene that reports on Runx 2 activity and negatively correlated with ER $\alpha$ mRNA (Figure 1B), and expression of SNAI2 was associated with BCa metastasis in general and bone metastasis in particular (Figure 5A-D).

SNAI2 likely plays different roles during various stages of $\mathrm{BCa}$ progression, and its ability to transcriptionally repress E-cadherin and induce EMT is well documented [3-5,49-51]. The role of SNAI2 downstream of Runx2 in $\mathrm{BCa}$ is reminiscent of the role of its homologue, SNAI1, in EMT and metastasis of breast, ovarian, colon, lung and squamous cell carcinomas [4]. However, SNAI1 is not stimulated by Runx2 in either MCF7 BCa [34] or C4-2B PCa cells [30]. Instead, it is SNAI2 that is strongly stimulated by Runx2 in $\mathrm{BCa}$ and PCa cells (Figure 2). Furthermore, SNAI2 and not SNAI1 was repressed by E2 in our study (data not shown), and SNAI2 and not SNAI1 exhibited an inverse correlation with $\mathrm{ER} \alpha$ and $\mathrm{E}$-cadherin in human BCa tumors [49]. Like Runx2, Twist1 has recently been shown to induce
SNAI2 expression, and SNAI2 was essential for Twist1mediated EMT of human mammary epithelial cells [50]. Thus, depending on context, either SNAI1 or SNAI2 regulate $\mathrm{BCa}$ metastasis, with the latter mediating the pro-metastatic activity of Runx 2 and Twist 1 as well as the anti-metastatic activity of E2.

It remains to be investigated whether Runx2 directly regulates SNAI2 transcription. On the one hand, there are several Runx-binding motifs upstream of the SNAI2 transcription start site (Additional file 3: Supplemental Figure 1A). However, Runx2 ChIP-seq analysis in C4-2B cells, where SNAI2 expression is also stimulated by Runx2 (Figure 1B), did not suggest occupancy of Runx2 at these SNAI2 upstream Runx motifs [52]. Instead, we believe that Runx2 indirectly stimulates SNAI2 expression via modulation of ETS signaling. This hypothesis is based on the observation that Runx2 down-regulated expression of SPDEF (Additional file 3: Supplemental Figure $1 \mathrm{~B}$ and [30]), a transcriptional inhibitor belonging to the ETS family, which suppresses tumor progression and metastasis [53] in part through direct inhibition of SNAI2 expression [54]. Indeed, our Runx2 ChIP-seq analysis in C4-2B/Rx2 ${ }^{\text {dox }}$ cells [52] demonstrated strong occupancy of the SPDEF transcription start site by Runx2 (Additional file 3: Supplemental Figure 1C). We are currently investigating how such Runx2 occupancy represses SPDEF transcription, and which of the many ETS sites upstream of the SNAI2 transcription start site (Additional file 3: Supplemental Figure 1A) mediate its repression by SPDEF and/or its activation by other members of the ETS family. Regardless of the precise mechanism by which Runx2 controls SNAI2, expression of the two is tightly correlated in $\mathrm{BCa}$ tumors (Figure 1D). In fact, much of the reported association between Runx2 expression and BCa metastasis [22] is attributable to SNAI2. Indeed, the results of our independent analysis validating the association of Runx2 with metastasis (Additional file 4) are remarkably similar to those demonstrating the association of SNAI2 with metastasis (Figure 5).

The anti-Runx2/SNAI2, anti-metastatic properties of E2 signaling in $\mathrm{BCa}$ cells may be relevant for early in vivo metastatic events (Figure $5 \mathrm{E}$ ), and possibly to targeting $\mathrm{BCa}$ metastasis to non-osseous tissues (Figure 5FG). However, they appear less relevant for bone 
metastasis. Whereas SNAI2 expression is associated with bone-seeking primary $\mathrm{BCa}$ tumors and $\mathrm{BCa}$ bone metastasis even more strongly than with lung or brain metastasis, ER $\alpha$ is negatively associated with only non-osseous metastasis (Figure 5). In fact, consistent with previous reports [9,55], the correlation between ER $\alpha$ expression and bone metastasis was positive, not negative in our cohort (Figure $5 \mathrm{H}$ ); $\mathrm{BCa}$ tumors that metastasized to bone were mostly ER-positive (Figure $5 \mathrm{Q}$ ) and $\mathrm{BCa}$ bone metastases co-expressed high levels of Runx2/ SNAI2 and ER $\alpha$ (Figure $5 \mathrm{~V}$ ). The bone-seeking property that ER $\alpha$ bestows on $\mathrm{BCa}$ cells may be counteracted during the first two years after surgery by the general anti-metastatic property of estrogens, resulting in a total neutral effect, but at the end it is the former that prevails (Figure $5 \mathrm{H}$ ). Possibly, activation of bone-seeking pathways in primary BCa cells, such as Src1 $[8,9]$, results in the stimulation of SNAI2 and other Runx2-regulated genes despite high levels of ER $\alpha$.

\section{Conclusions}

Runx2 stimulates EMT and invasiveness in MCF7 BCa cell cultures, adding to the mounting evidence for its role in metastasis. Our data suggest that E2 attenuates $\mathrm{BCa}$ metastasis by antagonizing Runx2. Indeed, EMT and invasiveness of MCF7 cells were severely compromised by E2 specifically after induction of Runx2. The linkage between the pro- and anti-metastatic properties of Runx2 and E2, respectively, is attributable in part to SNAI2, which is upregulated by Runx 2 and downregulated by E2. Furthermore, we observe a strong positive association between Runx2 and SNAI2 expression, a negative association between ESR1 and SNAI2, and a positive correlation between SNAI2 expression and metastasis in BCa tumors. These observations are consistent with the hypothesis that unopposed stimulation of Runx2 target genes such as SNAI2 in ER-negative tumors contributes to their aggressive metastatic phenotype. However, the relationship between ER expression and metastasis is more complicated in bone-seeking tumors. Here, the negative correlation between SNAI2 and ER is weak, and the anti-metastatic property of ER is likely masked by an opposite property, which ultimately prevails. Mimicking ER signaling to specifically antagonize Runx2 and SNAI2 offers a research avenue towards the development of novel therapeutic approaches for the management of $\mathrm{BCa}$ patients who fail first line therapy.

\section{Additional material}

Additional file 1: Oligonucleotide sequences used in this study. List of primer pair sequences for qRT-PCR and shRNA sequences.
Additional file 2: The complete list of the 'common' genes. The complete list of the 'common' genes, independently regulated by Runx2 and E2 in MCF7/Rx2 ${ }^{\text {dox }}$ cells are depicted along with respective fold changes and $p$ values.

Additional file 3: Potential Mechanisms Linking Runx2 to SNAI2. Based on the observation that Runx2 down-regulated expression of SPDEF and strong occupancy of the SPDEF transcription start site by Runx2 we hypothesize that Runx2 indirectly stimulates SNAI2 expression in part via modulation of ETS signaling.

Additional file 4: Association of Runx2 activity with metastasis. Runx2 activity was associated with both osseous and non-osseous metastases. Bone-seeking $\mathrm{BCa}$ tumors exhibit an unusual combination of high RUNX2 activity and high ERo levels.

\section{Abbreviations}

BCa: breast cancer; DAVID: Database for Annotation: Visualization and Integrated Discovery; dox: doxycycline; E2: estradiol; EMT: epithelialmesenchymal transition; ERa: estrogen receptor alpha; IPA: Ingenuity Pathway Analysis; PCa: prostate cancer; RMA: Robust Multiarray Averaging; SNAI2: snail homolog 2; SPDEF: SAM pointed domain-containing ets transcription factor.

\section{Acknowledgements}

We thank USC's Dr. Susan Groshen at the Norris Cancer Center Biostatistics Services Core for guidance with data analysis, Ms. Meng Li at the Bioinformatics Service Program, Norris Medical Library for helpful discussions, and Ms. Yunfan Shi for excellent technical support. This work was funded by $\mathrm{NIH}$ grants RO1 DK071122 and DK071122S1 to BF, who holds the J. Harold and Edna L. LaBriola Chair in Genetic Orthopedic Research at USC. ZB is funded by NIH grant RO1 HL089445 and holds the Ralph Edgington Chair in Medicine, DT holds the Priscilla and Art Ulene Chair in Women's Cancer.

\section{Author details}

'Department of Biochemistry \& Molecular Biology, Keck School of Medicine of the University of Southern California, 2250 Alcazar Street, Los Angeles, CA 90033 USA. ${ }^{2}$ Institute for Genetic Medicine, Keck School of Medicine of the University of Southern California, 2250 Alcazar Street, Los Angeles, CA 90033 USA. ${ }^{3}$ Department of Orthopedic Surgery, Keck School of Medicine of the University of Southern California, 1200 N. State Street, Los Angeles, CA 90033 USA. ${ }^{4}$ Bioinformatics Service Program, Norris Medical Library, University of Southern California, 2003 Zonal Ave, Los Angeles, CA 90089 USA.

${ }^{5}$ Department of Medicine, Keck School of Medicine of the University of Southern California, 1441 East Lake Ave, Los Angeles, CA 90033 USA. ${ }^{6}$ Will Rogers Institute Pulmonary Research Center, Keck School of Medicine of the University of Southern California, 2020 Zonal Avenue, Los Angeles, CA 90033 USA.

\section{Authors' contributions}

NOC, SKB and GHL performed the experiments. NOC and YBC performed the bioinformatics analyses. NOC, MK, ZB, DT and BF designed the study and wrote the manuscript. All authors read and approved the final manuscript.

\section{Competing interests}

The authors declare that they have no competing interests.

Received: 6 July 2011 Revised: 25 October 2011

Accepted: 9 December 2011 Published: 9 December 2011

\section{References}

1. Thiery JP, Acloque H, Huang RY, Nieto MA: Epithelial-mesenchymal transitions in development and disease. Cell 2009, 139:871-890.

2. Nguyen DX, Bos PD, Massague J: Metastasis: from dissemination to organspecific colonization. Nat Rev Cancer 2009, 9:274-284.

3. Foubert E, De Craene B, Berx G: Key signalling nodes in mammary gland development and cancer. The Snail1-Twist1 conspiracy in malignant breast cancer progression. Breast Cancer Res 2010, 12:206. 
4. Peinado H, Olmeda D, Cano A: Snail, Zeb and bHLH factors in tumour progression: an alliance against the epithelial phenotype? Nat Rev Cancer 2007, 7:415-428.

5. Nieto MA: The snail superfamily of zinc-finger transcription factors. Nat Rev Mol Cell Biol 2002, 3:155-166.

6. Roodman GD: Mechanisms of bone metastasis. N Eng J Med 2004, 350:1655-1664.

7. Jemal A, Siegel R, Ward E, Hao Y, Xu J, Thun MJ: Cancer statistics, 2009. CA CancerJ Clin 2009, 59:225-249.

8. Kang Y, Siegel PM, Shu W, Drobnjak M, Kakonen SM, Cordon-Cardo C, Guise TA, Massague J: A multigenic program mediating breast cancer metastasis to bone. Cancer Cell 2003, 3:537-549.

9. Zhang XH, Wang Q, Gerald W, Hudis CA, Norton L, Smid M, Foekens JA, Massague J: Latent bone metastasis in breast cancer tied to Srcdependent survival signals. Cancer Cell 2009, 16:67-78.

10. Henderson IC: Risk factors for breast cancer development. Cancer 1993, 71:2127-2140.

11. Ma H, Bernstein L, Pike MC, Ursin G: Reproductive factors and breast cancer risk according to joint estrogen and progesterone receptor status: a meta-analysis of epidemiological studies. Breast Cancer Res 2006, 8:R43

12. Yager JD, Davidson NE: Estrogen carcinogenesis in breast cancer. N Engl J Med 2006, 354:270-282

13. Chlebowski RT, Hendrix SL, Langer RD, Stefanick ML, Gass M, Lane D, Rodabough RJ, Gilligan MA, Cyr MG, Thomson CA, Khandekar J Petrovitch H, McTiernan A, WHI Investigators: Influence of estrogen plus progestin on breast cancer and mammography in healthy postmenopausal women: the Women's Health Initiative Randomized Trial. JAMA 2003, 289:3243-3253.

14. Pike MC, Krailo MD, Henderson BE, Casagrande JT, Hoel DG: 'Hormonal' risk factors, 'breast tissue age' and the age-incidence of breast cancer. Nature 1983, 303:767-770.

15. Sotiriou C, Piccart MJ: Taking gene-expression profiling to the clinic: when will molecular signatures become relevant to patient care? Nat Rev Cancer 2007, 7:545-553.

16. Anderson GL, Limacher M, Assaf AR, Bassford T, Beresford SA, Black $H$ Bonds D, Brunner R, Brzyski R, Caan B, Chlebowski R, Curb D, Gass M, Hays J, Heiss G, Hendrix S, Howard BV, Hsia J, Hubbell A, Jackson R, Johnson KC, Judd H, Kotchen JM, Kuller L, LaCroix AZ, Lane D, Langer RD, Lasser N, Lewis CE, Manson J, et al: Effects of conjugated equine estrogen in postmenopausal women with hysterectomy: the Women's Health Initiative randomized controlled trial. JAMA 2004, 291:1701-1712.

17. Ellis MJ, Gao F, Dehdashti F, Jeffe DB, Marcom PK, Carey LA, Dickler MN, Silverman P, Fleming GF, Kommareddy A, Jamalabadi-Majidi S, Crowder R, Siegel BA: Lower-dose vs high-dose oral estradiol therapy of hormone receptor-positive, aromatase inhibitor-resistant advanced breast cancer: a phase 2 randomized study. JAMA 2009, 302:774-780.

18. Maynadier M, Nirde P, Ramirez JM, Cathiard AM, Platet N, Chambon M, Garcia M: Role of estrogens and their receptors in adhesion and invasiveness of breast cancer cells. Adv Exp Med Biol 2008, 617:485-491.

19. Platet N, Cunat S, Chalbos D, Rochefort H, Garcia M: Unliganded and liganded estrogen receptors protect against cancer invasion via different mechanisms. Mol Endocrinol 2000, 14:999-1009.

20. Maynadier M, Ramirez JM, Cathiard AM, Platet N, Gras D, Gleizes M, Sheikh MS, Nirde P, Garcia M: Unliganded estrogen receptor alpha inhibits breast cancer cell growth through interaction with a cyclindependent kinase inhibitor (p21(WAF1)). FASEB J 2008, 22:671-681.

21. Platet N, Cathiard AM, Gleizes M, Garcia M: Estrogens and their receptors in breast cancer progression: a dual role in cancer proliferation and invasion. Crit Rev Oncol Hematol 2004, 51:55-67.

22. Onodera Y, Miki Y, Suzuki T, Takagi K, Akahira J, Sakyu T, Watanabe M, Inoue S, Ishida T, Ohuchi N, Sasano H: Runx2 in human breast carcinoma: its potential roles in cancer progression. Cancer Sci 2010, 101:2670-2675.

23. Frenkel B, Hong A, Baniwal SK, Coetzee GA, Ohlsson C, Khalid O, Gabet Y: Regulation of adult bone turnover by sex steroids. J Cell Physiol 2010, 224:305-310.

24. Blyth K, Vaillant F, Jenkins A, McDonald L, Pringle MA, Huser C, Stein T, Neil J, Cameron ER: Runx2 in normal tissues and cancer cells: A developing story. Blood Cells Mol Dis 2010, 45:117-123.

25. Otto F, Thornell AP, Crompton T, Denzel A, Gilmour KC, Rosewell IR, Stamp GW, Beddington RS, Mundlos S, Olsen BR, Selby PB, Owen MJ:
Cbfa1, a candidate gene for cleidocranial dysplasia syndrome, is essential for osteoblast differentiation and bone development. Cell 1997, 89:765-771.

26. Komori T, Yagi H, Nomura S, Yamaguchi A, Sasaki K, Deguchi K, Shimizu Y, Bronson RT, Gao YH, Inada M, Sato M, Okamoto R, Kitamura Y, Yoshiki S, Kishimoto T: Targeted disruption of Cbfa1 results in a complete lack of bone formation owing to maturational arrest of osteoblasts. Cell 1997, 89:755-764.

27. Javed A, Barnes GL, Pratap J, Antkowiak T, Gerstenfeld LC, van Wijnen AJ, Stein $J$, Lian JB, Stein GS: Impaired intranuclear trafficking of Runx2 (AML3/CBFA1) transcription factors in breast cancer cells inhibits osteolysis in vivo. Proc Natl Acad Sci USA 2005, 102:1454-1459.

28. Pratap J, Imbalzano KM, Underwood JM, Cohet N, Gokul K, Akech J, van Wijnen AJ, Stein JL, Imbalzano AN, Nickerson JA, Lian JB, Stein GS: Ectopic runx2 expression in mammary epithelial cells disrupts formation of normal acini structure: implications for breast cancer progression. Cancer Res 2009, 69:6807-6814

29. Pratap J, Wixted JJ, Gaur T, Zaidi SK, Dobson J, Gokul KD, Hussain S, van Wijnen AJ, Stein JL, Stein GS, Lian JB: Runx2 transcriptional activation of Indian Hedgehog and a downstream bone metastatic pathway in breast cancer cells. Cancer Res 2008, 68:7795-7802.

30. Baniwal SK, Khalid O, Gabet Y, Shah RR, Purcell DJ, Mav D, Kohn-Gabet AE, Shi Y, Coetzee GA, Frenkel B: Runx2 transcriptome of prostate cancer cells: insights into invasiveness and bone metastasis. Mol Cancer 2010, 9:258

31. Akech J, Wixted JJ, Bedard K, van der Deen M, Hussain S, Guise TA, van Wijnen AJ, Stein JL, Languino LR, Altieri DC, Pratap J, Keller E, Stein GS, Lian JB: Runx2 association with progression of prostate cancer in patients: mechanisms mediating bone osteolysis and osteoblastic metastatic lesions. Oncogene 2010, 29:811-821.

32. Pratap J, Lian JB, Stein GS: Metastatic bone disease: role of transcription factors and future targets. Bone 2011, 48:30-36.

33. Khalid O, Baniwal SK, Purcell DJ, Leclerc N, Gabet Y, Stallcup MR, Coetzee GA, Frenkel B: Modulation of Runx2 activity by estrogen receptor-alpha: implications for osteoporosis and breast cancer. Endocrinology 2008, 149:5984-5995.

34. Chimge NO, Baniwal SK, Luo J, Coetzee S, Khalid O, Berman B, Tripathy D, Ellis MJ, Frenkel B: Opposing effects of Runx2 and estradiol on breast cancer cell proliferation: in vitro identification of reciprocally-regulated gene signature related to clinical letrozole responsiveness. Clin Cancer Res.

35. Emami KH, Nguyen C, Ma H, Kim DH, Jeong KW, Eguchi M, Moon RT, Teo JL, Kim HY, Moon SH, Ha JR, Kahn M: A small molecule inhibitor of beta-catenin/CREB-binding protein transcription [corrected]. Proc Nat Acad Sci USA 2004, 101:12682-12687.

36. Baniwal SK, Little GH, Chimge NO, Frenkel B: Runx2 controls a feedforward loop between androgen and prolactin-induced protein (PIP) in stimulating T47D cell proliferation. J Cell Physiol .

37. Bos PD, Zhang XH, Nadal C, Shu W, Gomis RR, Nguyen DX, Minn AJ, van de Vijver MJ, Gerald WL, Foekens JA, Massagué J: Genes that mediate breast cancer metastasis to the brain. Nature 2009, 459:1005-1009.

38. Minn AJ, Gupta GP, Siegel PM, Bos PD, Shu W, Giri DD, Viale A, Olshen AB, Gerald WL, Massague J: Genes that mediate breast cancer metastasis to lung. Nature 2005, 436:518-524.

39. Wang $Y$, Klijn JG, Zhang Y, Sieuwerts AM, Look MP, Yang F, Talantov D, Timmermans M, Meijer-van Gelder ME, Yu J, Jatkoe T, Berns EM, Atkins D, Foekens JA: Gene-expression profiles to predict distant metastasis of lymph-node-negative primary breast cancer. Lancet 2005, 365:671-679.

40. Huang da W, Sherman BT, Lempicki RA: Systematic and integrative analysis of large gene lists using DAVID bioinformatics resources. Nat Protoc 2009, 4:44-57.

41. Williams SA, Harata-Lee Y, Comerford I, Anderson RL, Smyth MJ, McColl SR: Multiple functions of CXCL12 in a syngeneic model of breast cancer. Mol Cancer 2010, 9:250

42. Ghavami S, Chitayat S, Hashemi M, Eshraghi M, Chazin WJ, Halayko AJ Kerkhoff C: S100A8/A9: a Janus-faced molecule in cancer therapy and tumorgenesis. Eur J Pharmacol 2009, 625:73-83.

43. Ma X, Yang $Y$, Wang $Y$, An G, LV G: Small interfering RNA-directed knockdown of S100A4 decreases proliferation and invasiveness of osteosarcoma cells. Cancer Lett 299:171-181. 
44. Kwak JM, Lee HJ, Kim SH, Kim HK, Mok YJ, Park YT, Choi JS, Moon HY: Expression of protein S100A4 is a predictor of recurrence in colorectal cancer. World J Gastroenterol 2010, 16:3897-3904.

45. Miettinen PJ, Ebner R, Lopez AR, Derynck R: TGF-beta induced transdifferentiation of mammary epithelial cells to mesenchymal cells: involvement of type I receptors. J Cell Biol 1994, 127:2021-2036.

46. Moustakas A, Heldin CH: Signaling networks guiding epithelialmesenchymal transitions during embryogenesis and cancer progression. Cancer Sci 2007, 98:1512-1520.

47. Vincent T, Neve EP, Johnson JR, Kukalev A, Rojo F, Albanell J, Pietras K Virtanen I, Philipson L, Leopold PL, Crystal RG, de Herreros AG, Moustakas A, Pettersson RF, Fuxe J: A SNAIL1-SMAD3/4 transcriptional repressor complex promotes TGF-beta mediated epithelial-mesenchymal transition. Nat Cell Biol 2009, 11:943-950.

48. Lambertini E, Franceschetti T, Torreggiani E, Penolazzi L, Pastore A, Pelucchi S, Gambari R, Piva R: SLUG: a new target of lymphoid enhancer factor-1 in human osteoblasts. BMC Mol Biol 2010, 11:13.

49. Ye Y, Xiao Y, Wang W, Yearsley K, Gao JX, Shetuni B, Barsky SH: ERalpha signaling through slug regulates E-cadherin and EMT. Oncogene 2010, 29:1451-1462.

50. Casas E, Kim J, Bendesky A, Ohno-Machado L, Wolfe CJ, Yang J: Snail2 is an essential mediator of Twist1-induced epithelial mesenchymal transition and metastasis. Cancer Res 2011, 71:245-254.

51. Bolos V, Peinado H, Perez-Moreno MA, Fraga MF, Esteller M, Cano A: The transcription factor Slug represses E-cadherin expression and induces epithelial to mesenchymal transitions: a comparison with Snail and E47 repressors. J Cell Sci 2003, 116:499-511.

52. Little GH, Noushmehr H, Baniwal SK, Berman BP, Coetzee GA, Frenkel B: Genome-wide Runx2 occupancy in prostate cancer cells suggests a role in regulating secretion. Nucleic Acids Res.

53. Steffan JJ, Koul HK: Prostate derived ETS factor (PDEF): a putative tumor metastasis suppressor. Cancer Lett 2011, 310:109-117.

54. Findlay VJ, Turner DP, Yordy JS, McCarragher B, Shriver MR, Szalai G, Watson PM, Larue AC, Moussa O, Watson DK: Prostate-derived ETS factor regulates epithelial-to-mesenchymal transition through both SLUGdependent and independent mechanisms. Genes Cancer 2011, 2:120-129.

55. Hess KR, Pusztai L, Buzdar AU, Hortobagyi GN: Estrogen receptors and distinct patterns of breast cancer relapse. Breast Cancer Res Treat 2003, 78:105-118.

doi:10.1186/bcr3073

Cite this article as: Chimge et al:: Regulation of breast cancer metastasis by Runx2 and estrogen signaling: the role of SNAI2. Breast Cancer Research 2011 13:R127.

\section{Submit your next manuscript to BioMed Central and take full advantage of:}

- Convenient online submission

- Thorough peer review

- No space constraints or color figure charges

- Immediate publication on acceptance

- Inclusion in PubMed, CAS, Scopus and Google Scholar

- Research which is freely available for redistribution

Submit your manuscript at www.biomedcentral.com/submit
Biomed Central 